\title{
The Influence of Hindu, Buddhist, and Chinese Culture on the Shapes of Gebyog of the Javenese Traditional Houses
}

\author{
Joko Budiwiyanto $^{1} \quad$ Dharsono $^{2} \quad$ Sri Hastanto $^{2} \quad$ Titis S. Pitana ${ }^{3}$
}

\begin{abstract}
Gebyog is a traditional Javanese house wall made of wood with a particular pattern. The shape of Javanese houses and gebyog develop over periods of culture and government until today. The shapes of gebyog are greatly influenced by various culture, such as Hindu, Buddhist, Islamic, and Chinese. The Hindu and Buddhist influences of are evident in the shapes of the ornaments and their meanings. The Chinese influence through Islamic culture developing in the archipelago is strong, mainly in terms of the gebyog patterns, wood construction techniques, ornaments, and coloring techniques. The nuance has been felt in the era of Majapahit, Demak, Mataram and at present. The use of ganja mayangkara in Javanese houses of the Majapahit era, the use of Chinese-style gunungan ornaments at the entrance to the Sunan Giri tomb, the saka guru construction technique of Demak mosque, the Kudusnese and Jeparanese gebyog motifs, and the shape of the gebyog patangaring of the house.
\end{abstract} Keywords: Hindu-Buddhist influence, Chinese influence, the shape of gebyog, Javanese house.

DOI: $10.7176 / \mathrm{ADS} / 79-09$

Publication date: December $31^{\text {st }} 2019$

\section{INTRODUCTION}

Gebyog, according to the Javanese-Indonesian Dictionary, is generally construed as a wooden wall. In the context of this study, gebyog is a wooden wall in a Javanese house with a particular pattern. The wall takes form of framed panels, shaping a particularly pattern, with the middle part functioning as a door and both the right and left sides of the door are given additional panels. At the top of the door are given panels following the patterns of the panels below it considering the height of the roof of the house. Some of the wooden panels used as gebyog elements are carved with krawang (embroidery) technique and ordinary carving technique, and some others are plain without carving. Gebyog is also termed skétêng, which refers to the word skat or space divider.

Wall is a visual construction of a building that encloses, separates, and protects the interior space (Ching, 2008: 5.02.). In modern architecture, based on its function, walls are categorized into two, namely structural and non-structural walls (Suptandar, 1999: 147). Structural walls include bearing walls, load bearing walls, and foundation walls. Wall functions as a load-bearing, both from above and from the side of it. It is designed to be durable, strong enough to bear the load put on it, and able to endure the pressure from the side.

Thus, wall needs to be arranged in a particular pattern that is synchronized with the stretch of the structure and the roof it bears. The non-structural wall consists of party wall, partition wall, and curtain wall. This type of wall is designed as a room divider which seals the space between rooms. Non-structural walls are more flexible and semi-permanent. The walls are sometimes knocked down because people must adjust to the needs of space division and space functions. Walls also provide protection and privacy in the interior spaces they form (Ching, 1996: 176). In the development, walls also function as decorative elements to beautify the room and form the atmosphere of space.

When referring to its function as a wall, gebyog of Javanese house belongs to non-structural wall because by its nature it constructively functions as a room divider instead of as a load bearer. It is visually used as an aesthetic and philosophical element. The gebyog of Javanese house is influenced by various culture, including Hindu and Buddha, which are reflected in numerous shapes of the ornaments with the philosophy they bring. Gebyog is also influenced by Chinese culture through the Muslim-Chinese communities who entered the archipelago. This research aims to determine the contribution of Chinese culture on the shape of Javanese house gebyog. To scrutinize this, the shape of gebyog is traced from the influence of Hindu-Buddhist culture and the influence of the Chinese-Muslim communites entering the nation. The first is found in Hindu-Buddhist temples in Central Java and East Java and written in Negarakertagama, while the later is traced from the construction of the mosques in Demak, Kudus and Mantingan, and some related relics.

\section{Literature Review can be found in the articles below.

\footnotetext{
${ }^{1} \mathrm{PhD}$ candidate at the Indonesia Institute of the Arts, Surakarta

2 Postgraduate Program of Indonesia Institute of the Arts, Surakarta

${ }^{3}$ Postgraduate Program of Sebelas Maret University Surakarta, Indonesia
}

Literature review regarding Chinese influence on the shape of gebyog and ornaments of traditional Javanese house

The book entitled "Sejarah Modern Indonesia 1200-2004" by Ricklefs (2005) explains that Chinese culture 
influenced Java through trading and the spread of Islam. The development of Islam in Indonesia, especially in Java, cannot be separated from the Chinese people who came to Indonesia.

"Runtuhnya Kerajaan Hindu-Jawa dan Timbulnya Negara-Negara Islam di Nusantara" by Slamet Mulyana (2005) describes that the collapse of Majapahit kingdom marked the end of the Hindu-Javanese kingdom and the beginning of Islamic kingdom, particularly in Java. The first Islamic kingdom in Java was established by R. Patah in Demak. In establishing the Islamic kingdom of Demak and spreading Islam in Java, he was assisted by the nine guardians (wali sanga), whom Mulyana recorded coming from China.

Handinoto (2010), in his book, "Pengaruh Pertukangan Cina Pada Bangunan Masjid Kuno di Jawa Abad 1516", in "Arsitektur dan Kota-kota di Jawa pada Masa Kolonial" discusses that Islam was brought to the archipelago in $15^{\text {th }}$ and $16^{\text {th }}$ century by the Chinese-Muslim communities. Evidence of physical relics can be tracked in the fields such as: Demak Mosque construction (especially saka tatal or pillars supporting the mosque), stony soil carvings in the Mantingan Mosque, decoration of plates and certain elements in the Menara Kudus Mosque in Kudus, wood carvings in Demak, Kudus and Jepara areas, and construction of the entrance gate of Sunan Giri's tomb in Gresik. The construction of the door of Sunan Giri's tomb and the shape of the ornaments decorated with exquisite Chinese-style carvings was also witnessed by Denys Lombard (1996) in his book "Nusa Jawa: Silang Budaya 2, Jaringan Asia".

\section{Methodology}

This study uses a qualitative method. It was conducted in Central Java, where the research objects were located. Data sources used in qualitative research include informants, artifacts, various images, and recordings (Sutopo, 2002: 50-54). According to Soedarsono, sources of qualitative research data include written sources, oral sources, artifacts, and recordings (Soedarsono, 2001: 128). Data sources incorporated in this study comprise of informants (oral sources), written sources (literature), objects/artifacts, and images.

Data were collected using interviews, observation, and literature study. Data accuracy and validity were measured by employing data triangulation. Data were later analyzed using descriptive qualitative and interpretative analyses, focusing on the determination of meaning, description, clarification and placement of data in each context (Faisal, 2005: 256, check Pitana, 2014: 26-27). For this purpose, the data obtained from interviews and field observations of visual objects, and literature data related to the research were arranged in a particular pattern referring to the main problems of the study. The procedure adopted in this analysis was not linear, but interactive, as revealed by Miles \& Huberman that the analysis process was carried out during and after data collection. The analysis process moves from the initial stage until the stage of conclusion drawing of study results (Sutopo, 2002: 94-96).

\section{RESULTS AND DISCUSSION}

The shape of gebyog always develops along with the development of the shape of the Javanese house and various contributing factors. The development can be seen visually from the variations in shape, construction, and material. The variety of shapes and construction reflects the influence of culture coming from outside. The materials were wood available in the local area. Along with the changing times, Javanese houses used exposed red bricks as walls and floors. After receiving the influence of Western culture, materials for home-building also developed, initialing the use of red bricks combined with finishing plaster, cast iron and glass. Gradually but confidently, the red brick walls then began to replace the existence of Javanese walls which were originally made of wood and bamboo. The Javanese-style walls were then replaced by plastered-brick walls. Therefore, this discussion was directed at the development of the shape of the Javanese house gebyog from time to time. The study began with the influence of Hindu-Buddhist culture in Central and East Java and then influence Muslim-Chinese communities in Demak.

\section{The Period of Hindu-Budhist Kingdom in Central Java}

The shape of Javanese gebyog in the era of Hindu-Budhist kingdoms in Central Java are traced back from various shapes of Javanese traditional houses engraved in the reliefs of Borobudur Temple. The reliefs depict several forms of wooden Javanese houses. Wooden buildings as places for living are obvious on the reliefs of Borobudur Temple, particularly on the enclosed feet of the temple. One of the shapes of houses found on the reliefs is Rumah panggung or houses built on stilts, with the upper part for staying and the lower part for storing goods (Budiwiyanto, 2011:6). The shapes include saddle, pyramid (tajug) and multi-story (Atmadi, 1984:7). The shapes of Javanese houses pictured on the reliefs at that time are believed to preserve the tradition for building from the previous eras (Tjahjono, 2002:51). Thoroughly observed, buildings with the space construction (built on stilts) were also found in that era. Javanese house with this construction shows that the walls were divided into three parts, middle, right, and left. The middle part took form of door, while the right and left parts were walls. The shape, construction, and material for walls were not been depicted clearly. The walls were square, without any pattern division, and plain. 

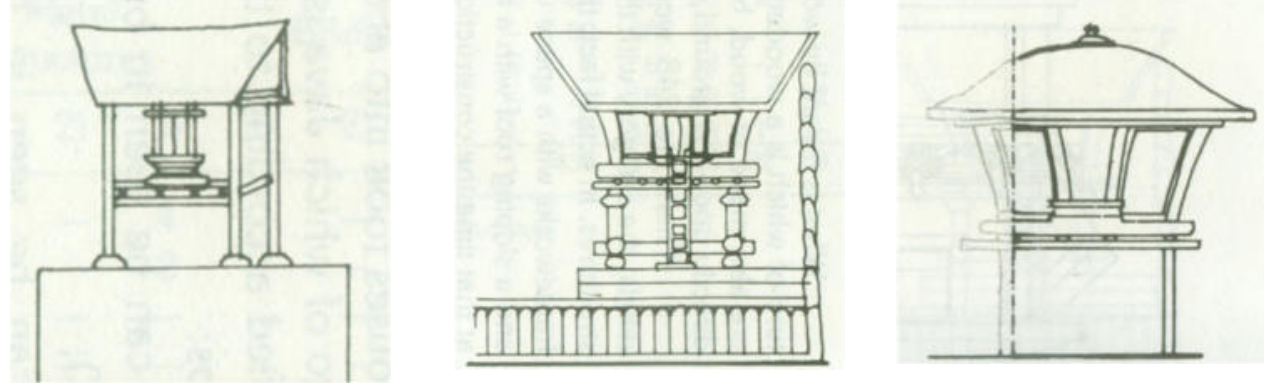

Figure 1: Severeal shapes of Javanese traditional wooden houses depicted in the reliefs of Borobudur Temple.

The walls were already patterned into three: middle, right, and left (Picture: Atmadi, 1994, 34-39)

In Javanese houses built on the land, the wall (gebyog) was divided into three parts. Those three parts consisted of four square-shaped, unpatterned coverings (possibly pillars), rectangular covering with a separation line (possibly door), and two patterned coverings with ornaments on the right and left parts (gebyog walls). The other picture shows a similar pattern, but the walls were given rhombic pattern. Both types of houses were decorated with ornaments.

The pattern of the wall is not obviously identified in these buildings. The shapes of the Javanese houses were simple, with a door in the middle and wooden walls on the right and the left. The unpatterned walls were possibly wooden boards arranged vertically. The walls inside the houses were ornamented and divided into several ornamented parts, possibly showing patterned and ornamented gebyog. The motifs for the ornaments were influenced by Hindu-Buddhist culture, reflected in various patterns, such as plants with stalks, flowers, birds, and a couple of snakes. The differences on the shapes of walls reflected the houses for different social status, the noble family and common people at that time.
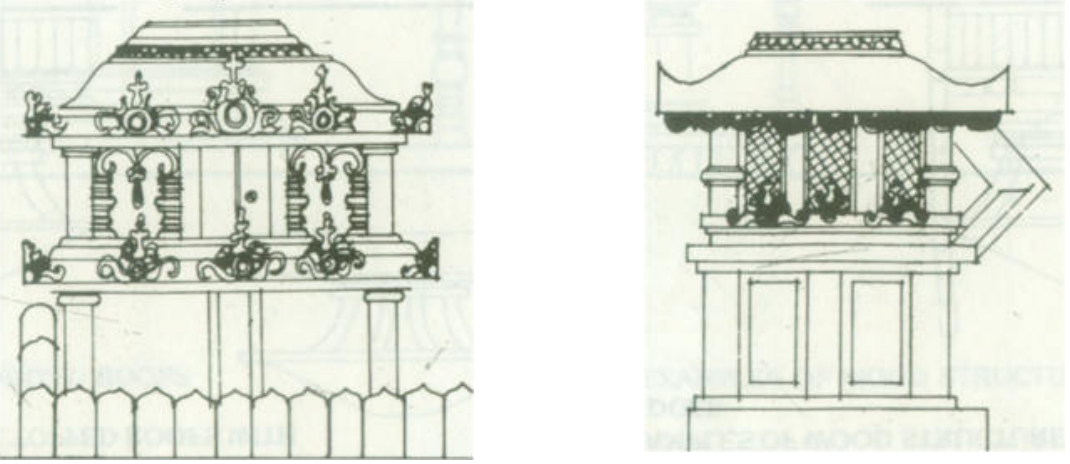

Figure 2: Several shapes of Javanese traditional houses made of wood construction depicted on the reliefs of Borobudur Temple (Picture: Atmadi, 1994, 34-39).

\section{The Period of Hindu-Buddhist Kingdom in East Java}

The greatness of Javanese houses in Hindu-Buddhist kingdom era in East Java was recorded in Negarakertagama book. The shapes of houses for living during this period (Majapahit kingdom) developed rapidly. At the beginning, the houses took forms of kampung limasan and joglo tajugan lawakan and developed into sinom (one terrace surrounding the house developed into two terraces). Joglo tajugan developed into joglo jompongan and then joglo lambangsari, joglo lambang teplok, and joglo semar tinandu or semar pinondong (Atmadi, 1984:17). Further, Atmadi explains that in the reign of Brawijaya V King, who married Muslim princess Campa, Majapahit palace was beutified with ganja mayangkara and santen with carvings of Campa combined with Balinese motif (Atmadi, 1984:17). The beauty of Majapahit architecture was also mentioned in Negarakertagama Book, Stanza VIII Number 1 and 2:

1) Itulah penghadap balai witana, tempat takhta, yang terhias serba bergas

Patangan masuk ke dalam istana timur, agak jauh dari pintu pertama

Ke istana selatan, tempat Singawardana, permaisuri, putra dan putrinya

Ke istana Utara, tempat Kertawardana. Ketiganya bagai kahyangan.

(They were in the witana hall, the place of the throne, decorated with all fine things

Patangan entered the eastern palace, a little far from the first gate

To the southern palace, a place for Singawardana, the empress, sons and daughters

To the north palace, a place for Kertawardana. The three places are like heaven.)

2) Semua rumah bertiang kuat, berukir indah, dibuat berwarna-warni (Mulyana, 1979: 278-279).

(All houses were built with strong pillars, gorgeously carved, and colorful) 
Referring to the information inscribed in Negarakertagama Stanza XI Part 2, architecture in Majapahit era developed well, as explained in that book, that the pillars were strong, decorated with beautiful and colorful carvings combined with red stone feet. The house pillars at that time were possibly engraved with various ornaments, like spiraling runners of plant, patran/rhombold shape, and praba, and with enameling technique (sungging) and prada technique. Red stone was already as pillar base. Feet made of red stone were likely the bases of pillars and foundation of the house. However, they can also refer to the ornaments made of clay for covering the base of pillar. Archeological evidence proving that clay was used as the material for pillar base cover found in Mojokerto is stored in Trowulan Museum. The miniatures of pillars illustrate various three-dimension ornaments such as lunglungan, curly shape, patran and human. Pillar ornaments depicting the life of people at that time were manifested in picturesque carvings. The ability of the communities in Majapahit period in processing clay was not only in making house pillars but also for making temples, fences surrounding the palace, ridge, roof, air ventilation, and various genthong or potteries (Majapahit Information Center in Trowulan).

Based on the archeological evidence in the forms of miniatures, Javanese houses in Majapahit period were tajug, gonjong, limasan, and kampung (collections of Trowulan Museum, Mojokerto, East Java). The roof was covered with various materials. Based on the materials, the roof of Javanese houses was categorized into four, namely roof made of clay (genteng), wood (sirab), bamboo, and black sugar palm fiber (ijuk). Clay and wood roofs were commonly used in tajug and limasan houses while bamboo and fiber were used in gonjong and kampong houses. Relics or miniatures of buildings (pillars, roof, ridge, ventilation, engraved brick, and wornout houses) show that the construction workers (experts) at that time were already skilled. Negarakertagama Book, Pupuh XI reveals that halls, such as witana hall for king, halls for soldiers, halls for women in the palace (keputren), and places for palace officials, show that palace was already well-structured, similar to Surakarta Sunannese Palace and Yogyakarta Sultanese Palace today. Both palaces also use witana halls, kaputren halls, kepatihan halls, srimanganti halls, and others. It is believed that the names of the halls in both palaces adopt the names in Majapahit. It is also believed that there was a building in Surakarta Sunannese Palace named witana hall, using similar name in the Majapahit era.

The shapes of Javanese houses during the Hindu period in East Java are also recognizable in some relics of the temples at that time, such as reliefs of Jago Temple, Jawi Temple, Panataran Temple, Surawana Temple, and Sukuh Temple. On some reliefs of Jago Temple, there are several forms of four-pillared, six-pillared and eightpillared buildings, functioning as dwellings, places of worship, parks/open spaces, palaces, and so on (Eni, 2017: 332). On the reliefs stored in the Trowulan Museum are several panels that illustrate groups of buildings. Javanese traditional houses are open and closed, as portrayed on the reliefs of temples in East Java. An open Javanese house (without a wall) was used as a pavilion (pendapa) to hold a community meeting at that time and has the same function at present. Javanese kampong house and gonjong house (with a roof made of fibers) were used by common people with the walls made of wood arranged vertically. For the royal family, the walls were conceivably made of wood, which were patterned and engraved like a gebyog. This refers to information provided in the Negarakertagama Pupuh XI.

\section{The Period of the Islamic Kingdom in Central Java and the Influence of Chinese Culture}

Demak was the first Islamic kingdom in Java. This kingdom was founded by Raden Patah in $1475 \mathrm{M}$. He is a descendant of King Brawijaya V and Princess Campa, as told in the Babad Tanah Jawi (History of the land of Java). The real name of Raden Patah is Jinbun. It is believed that Jinbun held a duchy in Demak. Demak was originally a small duchy, a part of Majapahit Kingdom, which developed rapidly with the support of Chinese Muslims. After Majapahit collapsed in 1478 AD, which was accompanied by the escape of the last king, Prabu Brawijaya (Mulyana, 2005: 29), Islam began to grow rapidly, and then Raden Patah began to build a force with the assistance of the wali sanga to establish the first Islamic kingdom in Java. According to Slamet Mulyana, wali sanga are Chinese people who spread Islam in Java.

Raden Patah ruled in 1500-1518 AD. After a few years ruling, he founded Demak Great Mosque (Masjid Agung Demak) in the middle of the Demak square (https://sejarahlengkap.com/ indonesia/kerajaan/peninggalankerajaan-demak). In constructing the mosque, Raden Patah was assisted by many skilled carpenters who were experts in making ships. They were local carpenters and the carpenters from Semarang who were Chinese subordinates of Gan Si Tjang. Gan Si Tjang, who was later known as Sunan Kalijaga, was a Chinese expert in shipbuilding and wood construction. Therefore, Demak mosque is a building with all parts made of wood, including the interior made using the construction of connecting ship pillars. Demak Great Mosque was built with the support of four main wooden pillars (saka guru) with a diameter of 1 meter. Of the four saka guru, there was a pole made of tatal (wood chips) and it was later called saka tatal (Tjahjono, 2002: 198). Saka tatal is a pole made of pieces of wood arranged neatly and attached using an iron plate. The construction of the mosque, with one saka tatal, is usually connected with the role of wali sanga or nine saints/theologians who spread Islam throughout Java. Saka tatal at Demak Great Mosque is recognized as the work of Sunan Kalijaga (Tjahjono, 2002: 95; Mulyana, 2005: 198). With his capacity in constructing ship made of wood, Sunan Kalijaga assembled wooden slats using boat construction technique with various considerations related to push and pull force, and later formed 
a large wooden pole as one of the saka guru in Demak Great Mosque.

Under the reign of Pati Unus, Demak succeeded in defeating Majapahit. Pati Unus then brought one of the porches of the Majapahit palace and placed it on the porch of Masjid Agung Demak. Thus, in other words, the porch of the mosque is part of the Majapahit palace, brought to Demak by Pati Unus after Majapahit collapsed. Considering that the porch was in a good condition, Pati Unus then moved to it Demak and used it as the porch of the Demak mosque. This building is still available at the Demak Great Mosque. Besides saka tatal with its interesting architecture, the mosque also has a unique main entrance gate. The door was named Bledeg (Lightning) Door. Bledeg Door is a door equipped with sculptures and it was made in 1466 by Ki Ageng Selo. It is said that this door was made by Ki Ageng Selo with striking lightning using the supernatural power he accepted when he was caught in the middle of a rice field. Bledeg Door was carved with various ornaments, such as bledeg head with open mouth and sharp teeth, crowns, flower vases, and plant motifs. The background of the carving is red. Bledeg head ornaments with an open mouth resembles the shape of a Chinese-style dragon head. Likewise, the crown ornament resembles a mountain and red background, showing the influence of Chinese style.

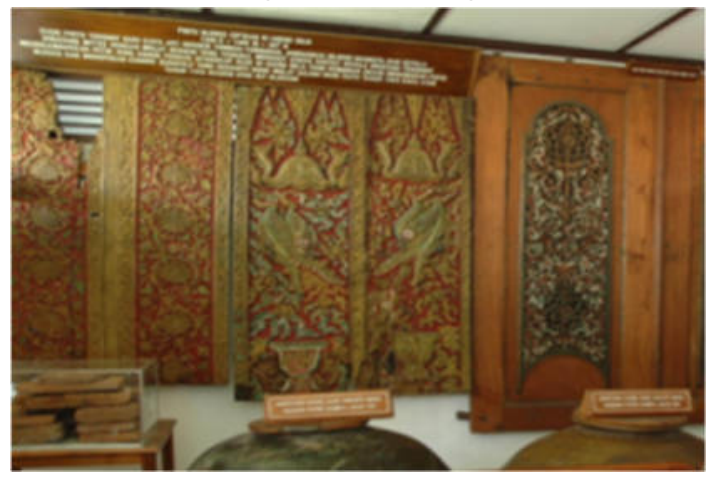

Figure 3: Bledeg Door as the main entrance to Demak Great Mosque built by Ki Ageng Selo

(Source: https://sejarahlengkap.com/indonesia/kerajaan/peninggalan-kerajaan-demak).

Besides Demak Great Mosque which was built with the help of Chinese carpenters, Kudus Mosque (Masjid Kudus) founded by Kyai Ja'far Sodig or Sunan Kudus was also influenced by Hindu and Chinese styles. The roof of the mosque consists of three layers, symbolizing the composition of temples, with three parts and steps resembling the forms of stepped pyramids in the Neolithic era. Similar to Demak Great Mosque, Kudus Mosque was built with wooden construction, presenting four saka guru. Like the Demak mosque, the main part of Masjid Kudus was built with wooden construction by presenting four pillars as the saka guru.

If the wood construction used to build Kudus Mosque was modeled on Demak Great Mosque that was done by Chinese artisans from Semarang, it can be said that the carpentry system was adopted by the local carpenters. Chinese influence on the building of Kudus Mosque can also be found on the porcelain plate decorations on the walls. The expertise of Chinese carpenters to process wood into building materials is also obvious in the residential housing located around the mosque. This area is often called the Kauman Village. Kauman is a village where Muslim middle class merchants lived around the mosque. This area was once inhabited by Muslim Chinese merchants and artisans, who socialized with local Muslim merchants. Finally, Chinese-Javanese families who converted to Islam joined the Kauman communities (Graaf H.J. De \& Th.G. Th Pigeaud, 1998: 183-186).

Several Kudusnese traditional houses with gebyog fully ornamented with carvings are still found in Kauman Village, which is located behind the Kudus Mosque. Local people believe that the carpentry and wood carvings in the Kudus Mosque area are inheritance from Kyai The Ling Siang, whose tomb is located near the Masjid Kudus and the year of his death is memorialized on the $15^{\text {th }}$ of Suro, the first month of the Javanese Calendar (Handinoto, 2010: 168). Sun Ging An, an expert in carving in Kudus in the $15^{\text {th }}$ century is also well-known (Handinoto, 2010: 161). Therefore Sunggingan was once famous as carving center in the area of Kudus. This style continues to develop and becomes one of the main developments in the architecture of Kudusnese house. This can be seen through the carving motifs such as krobongan, regol, and konsul in the Kudus traditional house and carved ornaments characterized by snake motif(Qurtuby, 2003: 138). Observing the gebyog patterns and krawang carving found in the Kauman area prompts the shapes of gebyog that are developing today in Kudus and Jepara, and patterns developing in other regions such as Surakarta and Yogyakarta.

Kudus Mosque was strongly influenced by Chinese and Hindu culture. Hindu influence is obvious in the shape of the roof, which is composed of three parts and the roof that takes form of a tajug. The minaret and entrance gates are similar to those of the Hindu temples of the Majapahit period. The building construction using bricks as the materials of the temples in Majapahit era also seen in the minarets of Kudus Mosque, as revealed by Wiyoso that brick buildings from the Majapahit era reappear on the gates and fences surrounding the mosque courtyard (Yudoseputro, 1990-1991: 44). 


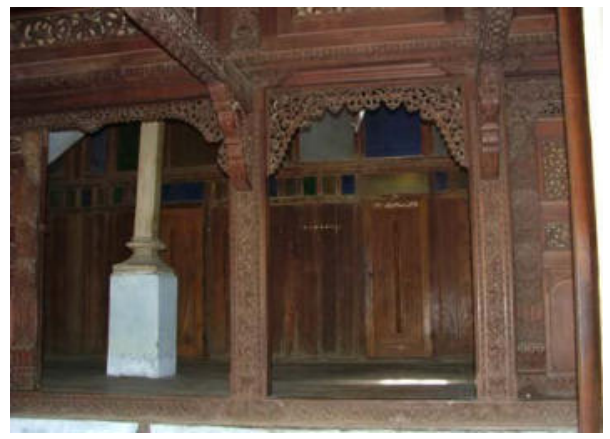

Figure 4: Kudusnese traditional house in Kauman village that is near the complex of Menara Kudus Mosque. In the past, this area was resided by Muslim Chinese merchants and carpenters who socialized with local Muslim merchants.

(Source Graaf H.J. De \& Th.G. Th. Pigeaud (1985), Handinoto, 2010).

Further, the greatness of Islam in Demak can be traced from the uniqueness of the Jepara Mosque (Masjid Jepara). This mouse was built by Ratu Kalinyamat when she ruled Jepara Regency. She married to Sunan Hadirin, a Chinese merchant who came from China to Java for trading. He was a great entrepreneur in shipping. He played an important role in supporting his wife governing the regency. Ratu Kalinyamat has a strong influence in the politics and military. Her role in military was proven by sending navy force to attack Portuguese in Malacca. This was supported by her husband as a shipmaster. As Ratu Kalinyamat's husband, he had a substantial role in driving the shipping, timber and carpentry industries in Jepara. Another interesting myth is the presence of Sunan Hadirin's foster father from China named Chi Hui Gwan. He was appointed the governor (patih) in Jepara under the name Patih Sungging Badar Duwung. When establishing the Mantingan mosque, Sunan Hadirin requested Patih Badar Duwung's assistance to decorate the mosque. With the help of local craftsmen from the surrounding area, he decorated the mosque with corals carved by the local communities. With the help of the local communities who could carve wood and stone under his guidance and the design he provided, the construction of Mantingan mosque was well completed (Gustami, 2004: 99).

The exterior and interior walls are adorned with blue pottery plates, while the wall next to the chamber for imam (a worship leader in Islam) and preacher is decorated with square reliefs resembling humans. On the walls of the Mantingan Mosque, there are stones with animal, plant and human motifs. The motifs of animals and humans are camouflaged so that they do not resemble the represented animals and humans because Islam do not allow people to make or paint animate beings (https://situsbudaya.id/647-2/). Graaf \& Pigeaud (1985: 133) assumed that the Chinese people in the $15^{\text {th }}$ and $16^{\text {th }}$ century contributed to the tradition of making furniture and fine wood carvings in Jepara (Handinoto, 2010: 172) in the past and at present. R. A. Kartini even said that she visited the burial place of Sultan Hadirin, in which there were many carvings and houses with Chinese patterns (Graaf \& Pigeaud, 1985: 131). The cultural heritage of Chinese Muslim communities, including graves and sculpture, can also be found beside the mosque. The tomb was the place to bury dead bodies of Muslims. Gravestones were build on the tomb and tombstones were put at the edges. To protect the tomb, a cupola-shaped building was establied on it. Cupolas could be either simple or lavish. The other way to protect the tomb was by putting rana (protective fences) (Yudoseputro, 1986: 19). Rana was at first made of wood with translucent carvings and was later replaced with stone materials with the same carvings.

The tombs of Javanese kings and saints (wali sanga) were typically protected by large cupola. The tajugshaped roof, doors, poles, and walls were made of carved wood and given a color called gebyog. As revealed by Soekmono, during the Islamic period, carvings especially on wood, particularly for cupola walls, shutter or rana and pillars were painted. Intensive use of gold and red colors were attractive (Soekmono, 1973: 90). According to Yudoseputro, the kelir (cloth) of shutter was decorated with gunungan (mountain pattern) because the lines or sketch surrounding the kelir resembles the motifs of mountains or trees on temples (1986: 20). The cupola walls for the tombs of wali sanga and Islamic propagators at that time were gebyog using Kudusnese and Jeparanese models. Gebyog was carved with krawang carvings, some were painted with gold (prada) and some others were natural. The tombs of Sunan Giri in Gresik, Sunan Kalijaga in Kadilangu, and Nyai Ageng Ngeran I. are the examples.

The influence of Islam in carving was also deep. Carvers at that time were prohibited to carve or paint sentient beings. With this prohibition, many carvers innovated the motifs. Motifs were camouflaged in shaping the figures of living creatures. New motifs were created and recognized, one of which was Arabic letter or calligraphy in ornamental art. However, this did not eliminate the motifs they had known before. They kept preserving the previous motifs. This view is reinforced by Soekmono, that ornamental art took the patterns from the Hindu period, such as leaves, flowers (lotus), coral hills, landscapes, and geometric lines, and drawings of dragons (Soekmono) 
1973: 87).

Decorative art was influenced by not only Hindu and Islam/Arab, but also China. The influence of ornamental art from China was evidenced on the carving engraved on the door of Sunan Giri tomb. The wood ornaments that were carved and painted and the way the mountain ornaments were made show the strong influence of Chinese culture (Lombard, 2, 1996: 48). A similar opinion was also expressed by Joko Sulistyo that the gebyog of Javanese house was heavily influenced by Chinese culture, such as the construction, patterns, ornaments, and colors (interview, 2018). Coloring techniques, including sungging, prada, and the use of red color, were introduced. The Kudusnese and Jeparanese gebyog continued to develop until the reign of Sultan Agung (1613-1645 AD), the king of the largest Islamic Mataram kingdom in Java. The beauty of wood carvings during Sultan Agung era was noticeable on the decoration of gebyog as a room divider with a door in the middle. Carvings presented the motifs of plants and flowers, the main motifs in the composition as decoration of shoots of leaves and flowers. On the top of gebyog, plant motifs were carved with the krawangan technique (Yudoseputro, 1986: 62).

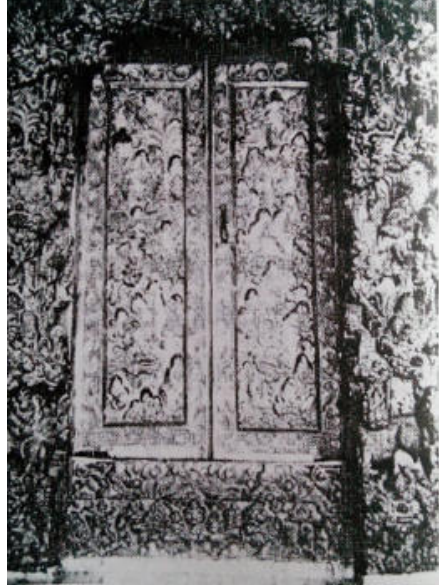

Figure 5: The entrance gate of Sunan Giri tomb, near Gresik, East Java. Wood decoration with mountain pattern is influenced by Chinese culture

(Source: Lombard, 2, 1996:48).

The walls of the buildings resembling the shape of Javanese gebyog can also be found in traditional Chinese houses and the Forbidden City of China in Beijing (https:/pxhere.com/id/ photo/ 1265589). The wall made of wood with a certain pattern and carved kerawang motif is very attractive. Other motifs, such as dragon decorative motif, geometric motif, and plants, are also recognizable. Those shapes are often found in temples in Java. Thong Hwie Kiong Temple, an ancient temple found in Purworejo, is one of the examples. This temple was first restored in $1888 \mathrm{AD}$ (http://www.nasionalisme.co/wah-kelenteng-kuno-thong-hwie- kiong-itu-bertuah/). The time it was built and the person who built it are not identified. A room divider resembling translculent carved gebyog is at the altar. Another sample is the Kim Hin Kiong Temple located at Jalan dr. Setia Budi Gang Kelenteng No 56, Pulopancikan Village, Gresik Sub-District, Gresik District, East Java (https://regional.kompas.com/read/2018/02/12/15263441/gaya-bersolek-kelen teng-kim-hin-kiong-help-yearnew-lunar).

The altar is decorated with wooden walls that are similar to carved gebyog. In Javanese temples, gebyog with Kudusnese/Jeparanese styles were commonly used in altar to decorate the most sacred place. In general, room dividers in temples, particularly in the altar, were decorated with carvings with the combination of prada, red, yellow and less dominating blue colors. This reminds us with the shape of gebyog patangaring in Javanese traditional house. Patangaring or divider is commonly decorated with gebyog, carved transparently with dragon, bird, tree, and flower motifs. Both are placed in sacred place for worshiping the gods. However, patangaring is a sacred part of Javanese traditional house, while altar is a part of temple, a place for worshiping in Buddha and $\mathrm{Kong} \mathrm{Hu} \mathrm{Cu}$. Both have equal position; they are sacred and used for worshiping to gods. 


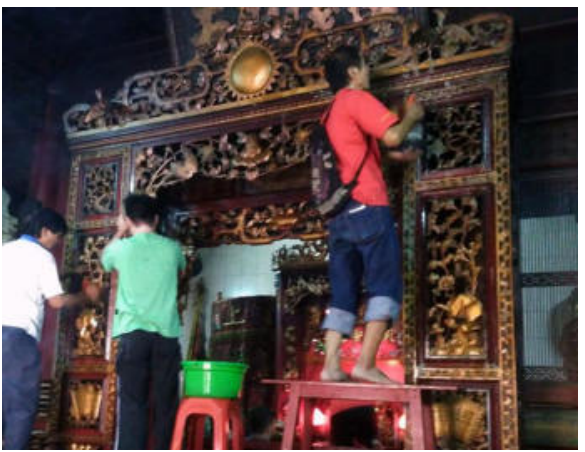

Figure 7: The parts of altar that are cleaned before Imlek celebration in Kim Hin Kiong Temple in Gresik (Source:

https://regional.kompas.com/read/2018/02/12/1526

3441/gaya-bersolek-kelenteng-kim-hin-kiongsambut-tahun-baru-imlek.)

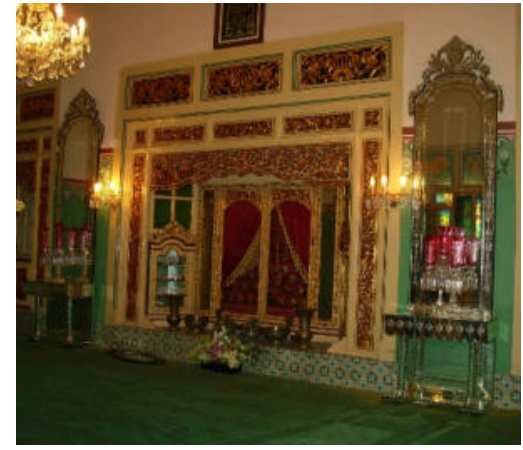

Figure 8: Gebyog patangaring in Javanese house as a place to worship Dewi Sri (the Goddes of Rice) (Foto: Budiwiyanto, 2007).

\section{CONCLUSION}

Gebyog as a Javanese house wall develops along with the development of Javanese house. The shape of Javanese gebyog is influenced by various culture, such as Hindu, Buddhist, Islam, and Chinese. The influence of Hinduism and Buddhism can be traced from the shape of Javanese houses found in the reliefs of temples in Central Java and East Java. The Chinese influence can be marked out from some of the ornaments in Javanese houses during the Majapahit era and the Demak kingdom, resulting in various shapes of gebyog. The touch of Hindu-Buddhist culture on the shape of gebyog is noticeable in numerous ornaments that adorn the gebyog, such as runners, flowers, birds, and a couple of snakes. Chinese influence is evident in the construction techniques, gebyog patterns, as well as mountain and dragon motifs. Some inspirations of Hindus, Buddhist, and Chinese culture on the shape of gebyog can be marked in the relics of the entrance to Demak Great Mosque (Bledeg Door), the shapes of gebyog in Muslim-Chinese community housing in Kauman, Kudus, and the entrance of the Sunan Giri's tomb in Gresik.

\section{References}

Atmadi, Parmono. 1984. “Apa Yang Terjadi Pada Arsitektur Jawa?,” Yogyakarta: Lembaga Javanologi. University Press,

1994. Some Architectural Design Principle of Temple in Java, Yogyakarta: Gadjah Mada

Budiwiyanto, Joko. 2011. Tinjauan Historis Perkembangan Rumah Tradisional Jawa dalam Gelar, Vol. 9 No.1. Surakarta: Institut Seni Indonesia Surakarta.

Ching, Francis D.K. 2008. Building Construction Illustrated, New Jersey: John Wiley \& Sons, Inc., 1996. Ilustrasi Desain Interior, Jakarta: Erlangga.

Eni, Sri Pare dan Adjeng Hidayah Tsabit. 2017. Arsitektur Kuno Kerajaan-Kerajaan Kediri, Singasari \& Majapahit Di Jawa Timur Indonesia, Jakarta: RaJawali Pers.

Faisal, Sanapiah. 2005. Format-format Penelitian Sosial, Jakarta: PT. Raja Grafindo Persada

Graaf H.J. De \& Th.G. Th. Pigeaud. 1985. Kerajaan-Kerajan Islam di Jawa, Peralihan dari Majapahit ke Mataram, Grafiti Pers: Jakarta.

. 1998. China Muslim Di Jawa Abad XV dan XVI Antara Historis dan Mitos (terjemahan dari: Chinese Muslim In Java in The 15 th And 16 th Centuries: The Malay Annals Of Semarang And Cerbon), Yogyakarta: PT. Tiara Wacana.

Gustami, SP. 2004. Seni Ukir Mebel Jepara, Kajian Estetik Melalui Pendekatan Multidisiplin, Yogyakarta: Kanisius.

2000. Studi Komparatif Gaya Seni Yogya-Solo, Yogyakarta:Yayasan Untuk Indonesia.

Handinoto. 2010. Pengaruh Pertukanngan Cina Pada Bangunan Masjid Kuno di Jawa Abad 15-16, dalam Arsitektur dan Kota-kota di Jawa pada Masa Kolonial, Yogyakarta: Graha Ilmu.

Lombard, Denys. 1996. Nusa Jawa: Silang Budaya 2, Jaringan Asia, Jakarta: Gramedia Pustaka Utama.

Mulyana, Slamet. 1979. Negarakertagama dan Tafsir Sejarahnya, Jakarta: Bhatara Karya Aksara.

Nusantara, Yogyakarta: LkiS

Pitana, Titis S., 2014. Teori Sosial Kritis Metode dan Aplikasinya, Purwokerto: STAIN Press.

Qurtuby, Sumanto A1. 2003. Arus Cina-Islam-Jawa, Yogyakarta: Inspeal Ahimsakarya Press. 
Ricklefs. 2005. Sejarah Indonesia Modern 1200-2004, Jakarta: Serambi.

Soedarsono, R.M. 2001. Metodologi Penelitian seni Pertunjukan dan seni Rupa, Bandung: Masyarakat Seni Pertunjukan Indonesia.

Soekmono, 1973. Sejarah Kebudayaan Indonesia Jilid 1,2, dan 3, Yogyakarta: Kanisius.

Suptandar, Pamudji. 1999. Desain Interior, Jakarta: Djambatan.

Sutopo. 2002. Metodologi Penelitian Kualitatif, Dasar Teori dan Terapannya dalam Penelitian, Surakarta: Sebelas Maret University Press.

Tjahjono, Gunawan. 2002. Indonesian Heritage, Arsitektur, Jakarta: Buku Antar Bangsa.

Yudoseputro, Wiyoso. 1990-1991. Seni Rupa Klasik, dalam Perjalanan Seni Rupa Indonesia Dari Zaman Prasejarah Hingga Masa Kini, Bandung: KIAS.

, 1986. Pengantar Seni Rupa Islam Indonesia, Bandung: Angkasa.

\section{Online References}

https://pxhere.com/id/photo/1265589

http://www.nasionalisme.co/wah-kelenteng-kuno-thong-hwie-kiong-itu-bertuah/

https://regional.kompas.com/read/2018/02/12/15263441/gaya-bersolek-kelenteng-kim-hin-kiong-sambut-tahunbaru-imlek.

http://www.nasionalisme.co/wah-kelenteng-kuno-thong-hwie-kiong-itu-bertuah/

https://id.wikipedia.org/wiki/Masjid_Mantingan

https://situsbudaya.id/647-2/

https://sejarahlengkap.com/indonesia/kerajaan/peninggalan-kerajaan-demak 